\title{
Interferon Stimulated Genes (Isgs): Novel Pregnancy Specific Biomarker In Buffaloes (Bubalus bubalis)
}

\author{
S.R. Mishra ${ }^{1}$, Mihir Sarkar ${ }^{2 *}$ \\ 'Department of Veterinary Physiology, College of Veterinary Science and Animal Husbandry, OUAT, Bhubabeswar, Odisha, 751003, India \\ ${ }^{2}$ Physiology \& Climatology Division, Indian Veterinary Research Institute, Izatnagar, Uttar Pradesh, 243122, India.
}

\section{Article Info}

\section{Article Notes}

Received: March 18, 2018

Accepted: April 20, 2018

\section{${ }^{*}$ Correspondence:}

Dr. Mihir Sarkar, Physiology \& Climatology Division, Indian Veterinary Research Institute, Izatnagar, Uttar Pradesh, 243122, India;

Telephone: +9105812310455

Fax: +91-0581 2301327,

E-mail: msarkar24@gmail.com

(c) 2018 Sarkar M. This article is distributed under the terms of the Creative Commons Attribution 4.0 International License.

\section{Keywords}

Pregnancy

ISG

Buffalo

\section{ABSTRACT}

Early embryonic mortality (EEM) has been shown to be the prime cause of pregnancy failure in domestic species incurring severe economic losses in terms of milk production in dairy cows in most of the tropical countries including India. Despite of the availability of various diagnosis methods for the pregnancy detection the domestic animals are still prone to reproductive failure before the onset of implantation. Recently, a group of genes called as interferon stimulated genes (ISG) have been shown to be expressed during peri-implanation period which could serve as a potential diagnostic marker for early detection of pregnancy in domestic species. The present mini review highlights the differential expression dynamics of interferon stimulated genes (ISG) during early pregnancy period in buffalo.

Water buffaloes (Bubalus bubalis) are the principal milk producing domestic animal in many countries of Asia including India. Indian buffaloes produce $65 \%$ of world's total buffalo milk production thereby contributes greatly to Indian economy. In spite of the high productivity, buffalo's posses several integral reproductive problems i.e. silent heat, delayed puberty, long post partum anestrous period and long intercalving period which markedly reduce their reproductive efficiency. Therefore, pregnancy diagnosis at an early stage of gestation could able to detect the embryonic loss and reproductive failure. Additionally, this might help to fertilize those non pregnant females again which may open up the chance of conception.

Nearly $30-40 \%$ of early embryonic mortatlity (EEM) was witnessed between days 8-17 following fertilization in small ruminants ${ }^{1}$, cattle ${ }^{2}$ and buffaloes ${ }^{3}$ resulting in reproductive failure and major economic losses. Therefore, we need to have some accurate method for the early detection of pregnancy which could identify the animals undergoing embryonic loss. Till date various diagnostic tools such as per-rectal palpation and trans-rectal ultrasonography are established but none could serve as a quintessential method for accurate diagnosis of pregnancy under field condition $s^{4-6}$. Thus, it is utmost important to unmask the novel roles of signalling molecules responsible for conceptus-maternal communication during early pregnancy. Based on the above facts, the present mini-review focuses on the expression dynamics of aforementioned ISG family during peri-implantation period in domestic animals including buffaloes. 
Interferon-tau (IFNT) seems to be a crucial signalling molecule between conceptus and mother, secreted from the trophectoderm cells of blastocysts during days 17 of pregnancy and increases with elongation of conceptus in ruminants $^{7-9}$. The IFNT expression was elevated during day 16-17 of pregnancy in cattle ${ }^{10}$. In another study in sheep, the IFNT expression began to rise during days 8-9, found to be highest during days 16-17 followed by a sharp decline to basal level ${ }^{11}$. Interestingly, some portion of IFNT secreted into the uterine cavity enters the uterine vein and directly triggers the expression of group of molecules known as interferon stimulated genes (ISGs) in both peripheral blood cells and the CL. The members of ISGs such as interferon-stimulated protein 15 (ISG15) $^{12}$, myxovirus resistance protein (MX) and 2'-5'oligoadenylate synthetase (OAS1) could play a paramount role in endometrial cells differentiation, implantation and conceptus development in early pregnancy ${ }^{13}$.

\section{Interferon stimulated gene 15 (ISG15) ubiquitin-like modifier}

ISG15 is popularly known as $17 \mathrm{kDa}$ protein and type I interferon. ISG15 was found to be expressed in uterus of $\operatorname{cow}^{14}$, buffalo ${ }^{15}$, ewe $\mathrm{e}^{16}$, sow ${ }^{17}$ and mare ${ }^{18}$. It has been indicated that, IFNT goes from uterine vein to systemic circulation and induces the ISGs expression in peripheral blood mononuclear cells (PBMCs) ${ }^{19,20}$. It is well known that, ISGs expression was not only induce maternal recognition of pregnancy (MRP) but also helpful for early detection of pregnancy in ruminants ${ }^{21-23}$. Likewise, administration of IFNT to uterine endometrium up surged ISG15 expression in PBMCs of ruminants ${ }^{23}$.

ISG15 gene expression was up-regulated from day 18 to 23 and down-regulated from day 23 to 45 and did not register any change on day 50 of pregnancy indicating higher expression of ISG15 in pregnant as compared to non-pregnant cows ${ }^{24,14}$. In contrast, Shirasuna et al. (2012) did not observe any change in expression pattern of ISG15 in pregnant and non-pregnant cows ${ }^{25}$. In a study conducted in cow, the ISG15 expression was shown to be significantly up-regulated on day 17 of the pregnancy ${ }^{21}$. The expression ISG15 transcript was noticed significantly higher during first 24-48 hours in pregnant sheep ${ }^{16,19}$, reached peak between days 13 to 19 and reverted to basal level on days 21 in uterine endometrium of pregnant sheep ${ }^{26}$. It has also been revealed that, the ISG15 transcript was consistently expressed throughout pregnancy followed by a dip in ISG15 transcript during late pregnancy ${ }^{27}$. In yet another study in sheep, the ISG15 expression was up-regulated on day 15, remained elevated till day 21 and its expression was dwindled on days 23 and 25 in PBMCs ${ }^{28}$.. Most recently, our study in buffalo demonstrated that, the ISG15 expression was increased between days 14 to 20 and then declined ${ }^{15}$. Taken together, ISG15 has been shown to modulate endometrial proteins thereby promote establishment and maintenance of pregnancy in ruminants ${ }^{29}$.

\section{Myxovirus resistance protein (MX)}

The IFNT intensifies the MX1 and MX2 expression in PBMCs of ruminants and could able to signal MRP ${ }^{23}$. The MX gene was known to be expressed in the uterus of pregnant cow, sheep, pig and mare ${ }^{30,31}$. In another study in pregnant ewes, the MX1 transcript levels was significantly upturned on days 15 , remained consistent till days 23 and then declined on days $25-30^{28}$. Furthermore, the MX1 expression was also noted to be elevated on days 15 in PBMCs of pregnant ewe $\mathrm{e}^{32}$ and $\mathrm{cow}^{33}$. In our recent study, the MX1 gene registered greatest expression on days 14, then gradually down-regulated up to days 20 and again increased on days 22 in pregnant buffaloes ${ }^{15}$. We have also witnessed that, the MX2 expression was up-regulated between days 14-20 with a significant peak on days 18 and then gradually ware off in pregnant buffaloes ${ }^{15}$. The expression of MX2 was also found to be higher between 24-48 $\mathrm{h}$ in pregnancy sheep ${ }^{16}$ and days 0-18 in pregnant heifers ${ }^{22}$. Additionally, the MX2 expression was stimulated by IFNT during days 12-17 and 15-21 in ewe and cow respectively ${ }^{34}$. Moreover, IFNT was shown to stimulate MX2 expression in PBMCs of ewe ${ }^{35}$.

\section{2'-5' oligoadenylate synthetase (OAS1)}

The IFNT has been shown to stimulate the OAS1 transcripts in PBMCs in pregnant ruminants ${ }^{21}$. The OAS1 expression was amplified during days $15-18$ in heifers ${ }^{36}$ and $\operatorname{cow}^{37}$. Shirasuna et al. (2012) documented that, the OAS1 expression did not vary in pregnant and nonpregnant cows ${ }^{25}$. The OAS1 mRNA expression was elevated within 24-48 $\mathrm{h}$ in PBMCs after initial signalling of IFNT in pregnant ewes ${ }^{16}$. However, the OAS1 protein expression was increased on days 15, maintained up to days 17 and then decreased on days 19 in pregnant ewes ${ }^{16}$. It has been illustrated that, interferons produced from bovine and ovine conceptus in early pregnancy i.e. bTP-1 and oTP-1 respectively, accentuates OAS1 expression in endometrium of pregnant cow and ewe ${ }^{38}$. In sow, the OAS1 expression did not reveal any significant change suggesting that the maintenance of pregnancy might be independent of OAS1 gene $^{39}$. In our recent study in buffaloes, we reported highest expression of OAS1 transcript on days 18 suggesting that OAS1 might serve as ideal pregnancy marker ${ }^{15}$.

\section{Conclusion}

A plethora of signalling molecules known as ISGs secreted from the conceptus are required for conceptusmother cross talk and induction of MRP following fertilization. Prominent expression of ISGs in uterine endometrium as well as in PBMCs during early pregnancy period may be indispensible for implantation and maintenance of pregnancy and may play a significant 
role as early pregnancy biomarkers. There is a dearth of information in this field of study and further research investigations should be envisaged to explore the exact molecular signalling and function of these ISGs which might alleviate EEM and could augment reproductive efficiency in domestic species.

\section{References}

1. Diskin MG, Morris DG. Embryonic and early foetal losses in cattle and other ruminants. Reproduction in Domestic Animals. 2008; 43: 260267.

2. Humblot P. Use of pregnancy specific proteins and progesterone assays to monitor pregnancy and determine the timing, frequencies and sources of embryonic mortality in ruminants. Theriogenology. 2001; 56: 1417-1433.

3. Thatcher WW, Meyer MD, Danet-Desnoyers G. Maternal recognition of pregnancy. Journal of Reproduction and Fertility. Supplement. 1995; 49: 15-28.

4. Buckrell BC. Application of ultrasonography in reproduction in sheep and goats. Theriogenology. 1988; 29: 71-84.

5. Haibel GK. Use of ultrasonography in the reproductive management of sheep and goats herd. Veterinary Clinics of North America. Food Animal Practices. 1990; 6: 597-613.

6. Romano JE, Larson JE. Accuracy of pregnancy specific protein-B test for early pregnancy diagnosis in dairy cattle. Theriogenology. 2010; 74: 932-939.

7. de Vries A, Bartolome J, Broaddus B. What is early pregnancy diagnosis worth? In Proceedings of the 2nd Florida Dairy Road. 2005; 31-41.

8. Roberts RM, Chen Y, Ezashi T, et al. Interferons and the maternalconceptus dialog in mammals. Seminars in Cell and Developmental Biology. 2008; 19:170-177.

9. Bazer FW. Pregnancy recognition signaling mechanisms in ruminants and pigs. Journal of Animal Science and Biotechnology. 2013; 4: 23.

10. Spencer TE, Johnson GA, Bazer FW, et al. Pregnancy recognition and conceptus implantation in domestic ruminants: roles of progesterone, interferons and endogenous retroviruses. Reproduction, Fertility, and Development. 2007; 19: 65-78.

11. Spencer TE, Bazer FW. Ovine interferon tau suppresses transcription of the estrogen receptor and oxytocin receptor genes in the ovine endometrium. Endocrinology. 1996; 137:1144-7

12. Bott RC, Ashley RL, Henkes LE, et al. Uterine vein infusion of interferon tau (IFNT) extends luteal life span inewes. Biology of Reproduction. 2010; 82: 725-735.

13. Spencer TE, Bazer FW. Conceptus signals for establishment and maintenance of pregnancy. Reproductive Biology and Endocrinology. 2004; 5: 49.

14. Gifford CA, Racicot K, Clark DS, et al. Regulation of interferonstimulated genes in peripheral blood leukocytes in pregnant and bred, nonpregnant dairy cows. Journal of Dairy Science. 2007; 90:274-80.

15. Thakur N, Singh G, Paul A, et al. Expression and molecular cloning of interferon stimulated genes in buffalo (Bubalus bubalis). Theriogenology. 2017; 100: 50-58.

16. Yankey SJ, Hicks BA, Carnahan KG, et al. Expression of the antiviral protein $\mathrm{Mx}$ in peripheral blood mononuclear cells of pregnant and bred, non-pregnant ewes. Journal of Endocrinology. 2001; 170:7-11.

17. Joyce MM, Burghardt RC, Bazer FW, et al. Interferon stimulated genes (ISGs) are induced in the endometrium of pregnant but not pseudopregnant pigs. Biology of Reproduction. 2003; 68: 230-238.

18. Klein C, Scoggin KE, Troedsson MH. The expression of interferon- stimulated gene 15 in equine endometrium. Reproduction in Domestic Animals. 2011; 46:692-698.

19. Oliveira JF, Henkes LE, Ashley RL, et al. Expression of interferon (IFN)stimulated genes in extrauterine tissues during early pregnancy in sheep is the consequence of endocrine IFN-tau release from the uterine vein. Endocrinology. 2008; 149:1252-1259.

20. Forde N, Carter F, Spencer TE, et al. Conceptus-induced changes in the endometrial transcriptome: how soon does the cow know she is pregnant? Biology of reproduction. 011; 85: 144-56.

21. Han H, Austin KJ, Rempel LA, et al. Low blood ISG15 mRNA and progesterone levels are predictive of non-pregnant dairy cows. Journal of Endocrinology. 2006; 191:505-12.

22. Stevenson JL, Dalton JC, Ott TL, et al. Correlation between reproductive status and steady-state messenger ribonucleic acid levels of the Myxovirus resistance gene, Mx2, in peripheral blood leukocytes of dairy heifers. Journal of Animal Science. 2007; 85:21-63.

23. Matsuyama S, Kojima T, Kato S, et al. Relationship between quantity of IFNT estimated by IFN-stimulated gene expression in peripheral blood mononuclear cells and bovine embryonic mortality after AI or ET. Reproductive Biology and Endocrinology. 2012; 1:10-21.

24. Austin KJ, Carr AL, Pru JK, et al. Localization of ISG15 and conjugated proteins in bovine endometrium using immunohistochemistry and electron microscopy. Endocrinology. 2004; 145: 967-975.

25. Shirasuna K, Matsumoto H, Kobayashi E, et al. Upregulation of interferon-stimulated genes and interleukin-10 in peripheral blood immune cells during early pregnancy in dairy cows. Journal of Reproduction and Developement. 2012; 58: 84-90.

26. Johnson GA, Spencer TE, Hansen TR, et al. Expression of the interferon tau inducible ubiquitin cross-reactive protein in the ovine uterus. Biology of Reproduction. 1999; 61: 312-318.

27. Joyce MM, White FJ, Burghardt RC, et al. Interferon stimulated gene 15 conjugates to endometrial cytosolic proteins and is expressed at the uterine-placental interface throughout pregnancy in sheep. Endocrinology. 2005; 146: 675-684.

28. Kose M, Kaya MS, Aydilek N, et al. Expression profile of interferon tau stimulated genes in ovine peripheral blood leukocytes during embryonic death. Theriogenology. 2016; 85: 1161-1166.

29. Johnson GA, Austin KJ, Van Kirk EA, et al. Pregnancy and interferontau induce conjugation of bovine ubiquitin cross-reactive protein to cytosolic uterine proteins. Biology of Reproduction 1998; 58:898-904

30. Ott TL, Yin J, Wiley AA, et al. Effects of the estrous cycle and early pregnancy on uterine expression of Mx protein in sheep (Ovis aries). Biology of Reproduction. 1998; 59: 784-794.

31. Shirozu T, Sasaki K, Kawahara M, et al. Expression dynamics of bovine MX genes in the endometrium and placenta during early to mid pregnancy. Journal of Reproduction and Development. 2016; 62:2935.

32. Mauffre V, Grimard B, Eozenou C, et al. Interferon stimulated genes as peripheral diagnostic markers of early pregnancy in sheep: a critical assessment. Animal. 2016; 10: 1856-1863.

33. Pugliesi G, Miagawa BT, Paiva YN, et al. Conceptus-induced changes in the gene expression of blood immune cells and the ultrasoundaccessed luteal function in beef cattle: how early can we detect pregnancy? Biology of Reproduction. 2014; 91: 95.

34. Ott TL, Heeke GV, Johnson HM, et al. Cloning and expression in S.Cerevisiae of a synthetic gene for the pregnancy recognition hormone ovinetrophoblast protein-1: purification and antiviral activity. Journal of Interferon Research 1991;11: 357-64

35. Buraqohain L, Kumar R, Nanda T, et al. Serum MX2 Protein as Candidate Biomarker for Early Pregnancy Diagnosis in Buffalo. Reproduction in Domestic Animal. 2016; 51: 453-60. 
36. Green JC, Okamura CS, Poock SE, et al. Measurement of interferon-tau (IFN- $\tau$ ) stimulated gene expression in blood leukocytes for pregnancy diagnosis within 18-20 days after insemination in dairy cattle. Animal Reproduction Science. 2010; 121: 24-33.

37. Short EC, Geisert RD, Helmer SD, et al. Expression of antiviral activity and induction of 2', 5'-oligoadenylate synthetase by conceptus secretory proteins enriched in bovine trophoblast protein-1. Biology of Reproduction. 1991; 44:261-268.
38. Taylor JL, Grossberg SE. Recent progress in interferon research: molecular mechanisms of regulation, action, and virus circumventin. Virus Research. 1990; 15: 1-25.

39. Harney JP, Bazer FW. Effect of porcine conceptus secretory proteins on interestrous interval and uterine secretion of prostaglandins. Biology of Reproduction. 1989; 41: 277-284. 